\title{
Characterization of pea (Pisum sativum) seed protein fractions
}

\author{
Luis A Rubio, * Alicia Pérez, Raquel Ruiz, M Ángeles Guzmán, Isabel \\ Aranda-Olmedo and Alfonso Clemente
}

\begin{abstract}
BACKGROUND: Legume seed proteins have to be chemically characterized in order to properly link their nutritional effects with their chemical structure.

RESULTS: Vicilin and albumin fractions devoid of cross-contamination, as assessed by mass peptide fingerprinting analysis, were obtained from defatted pea (Pisum sativum cv. Bilbo) meal. The extracted protein fractions contained 56.7-67.7 g non-starch polysaccharides $\mathbf{~ k g}^{-1}$. The vicilin fraction was higher than legumins in arginine, isoleucine, leucine, phenylalanine and lysine. The most abundant amino acids in the albumin fraction were aspartic acid, glutamic acid, lysine and arginine, and the amounts of methionine were more than double than those in legumins and vicilins. The pea albumin fraction showed a clear enrichment of protease inhibitory activity when compared with the seed meal. In vitro digestibility values for pea proteins were $0.63 \pm$ $0.04,0.88 \pm 0.04$ and $0.41 \pm 0.23$ for legumins, vicilins and albumins respectively.
\end{abstract}

CONCLUSION: Vicilin and albumin fractions devoid of cross-contamination with other proteins were obtained from pea seed meal. The vicilin fraction also contained low amounts of soluble non-starch polysaccharides and was enriched in isoleucine, leucine, phenylalanine and lysine. In vitro digestibility values for pea proteins were similar or even numerically higher than those for control proteins.

(c) 2013 Society of Chemical Industry

Keywords: albumins; legumins; Pisum sativum; protease inhibitors; protein digestibility; vicilins

\section{INTRODUCTION}

It is at present acknowledged that food proteins are not only a source of constructive and energetic compounds such as amino acids ( $A A$ ) but may also play a bioactive role and/or can be precursors of biologically active peptides with various physiological functions. The best-known examples of this are probably casein-derived peptides, which have been proved to possess immunomodulating, antihypertensive, antithrombotic and opioid activities. ${ }^{1}$ In this context, plant proteins and their derived protein hydrolysates are increasingly being used as an alternative to proteins from animal sources in human nutrition. ${ }^{2}$ Among plants, legume seeds such as soybean (Glycine max), beans (Phaseolus spp.), peas (Pisum sativum), lupins (Lupinus spp.) and lentils (Lens culinaris) represent rich sources of proteins, carbohydrates, several water-soluble vitamins and minerals. ${ }^{3}$ The dietary importance of legume seeds is expected to grow in the coming years owing to the protein (and other nutrients) demand of the increasing world population and to the need to reduce the risks related to consumption of animal food sources, especially in developed countries. ${ }^{4}$ Moreover, there is at present great interest in the use of home-grown protein sources such as legume seeds because of the high market price of soybean meal, which is entirely imported from non-European markets. Moreover, the forbidden use of genetically modified organism (GMO) feed ingredients and solvent-extracted oil seeds in organic farming increases the interest in alternative protein sources. ${ }^{5}$ In this context, field pea constitutes a significant sector of agricultural grain production, as approximately 25 million hectares are grown annually worldwide. ${ }^{6}$

It is generally recognized that grain legumes contribute effectively to a balanced diet and can prevent non-communicable diseases, including type II diabetes and cardiovascular diseases. ${ }^{7}$ However, which chemical components are responsible for the observed protective effects, their mechanism(s) of action and even the nutritional properties of seed constituents (proteins, carbohydrates, ether extract, fiber) in vivo are still unclear. Proteins in legume seeds represent from about $200 \mathrm{~g} \mathrm{~kg}^{-1}$ (dry weight) in pea and beans up to $380-400 \mathrm{~g} \mathrm{~kg}^{-1}$ in soybean and lupin. Traditionally, the classification of legume proteins is based on their solubility properties: albumins are soluble in water, globulins are soluble in salt water solutions and prolamins are soluble in ethanol/water solutions. ${ }^{8}$ Most of them are storage proteins, with the most abundant in grain legumes being globulins. These are generally classified as $7 \mathrm{~S}$ and $11 \mathrm{~S}$ globulins according to their sedimentation coefficients (S). The 75 and 115 globulins of pea are named vicilin and legumin respectively, so that the corresponding proteins of

Correspondence to: Luis A Rubio, Physiology and Biochemistry of Animal Nutrition (EEZ, CSIC), Profesor Albareda 1, E-18008 Granada, Spain. E-mail: Irubio@eez.csic.es

Physiology and Biochemistry of Animal Nutrition (EEZ, CSIC), Profesor Albareda 1, E-18008 Granada, Spain 


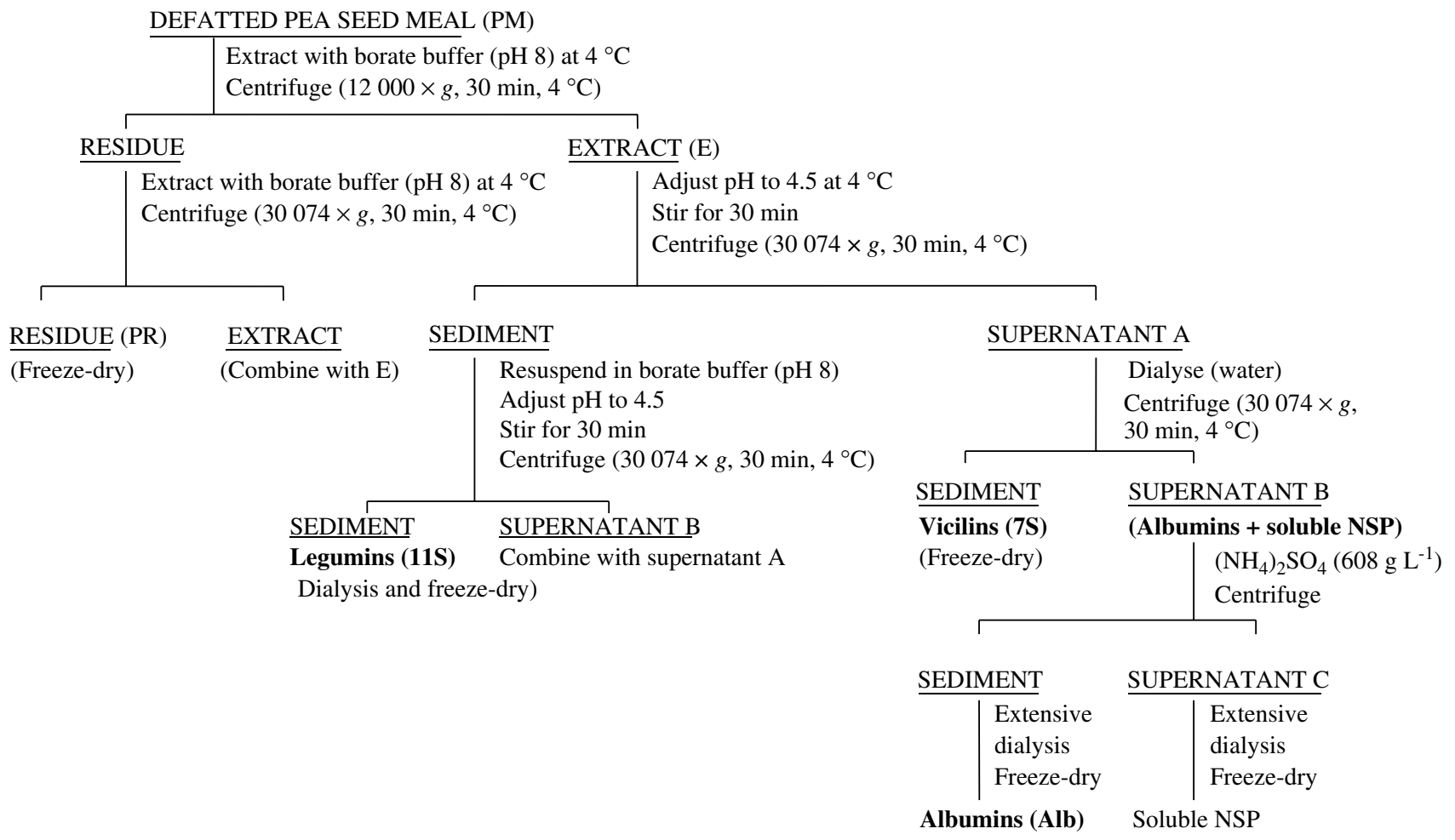

Figure 1. Procedure for extraction of pea (Pisum sativum cv. Bilbo) seed meal protein fractions.

other seeds are often indicated as vicilin- and legumin-like globulins. ${ }^{9}$ Both albumins and globulins have been claimed to induce a number of health beneficial effects (anticarcinogenic, antihypertensive, hypoglycemic, hypocholesterolemic, etc.) upon dietary consumption. ${ }^{4}$ Efforts towards large-scale procedures for protein fractionation from pea ${ }^{10}$ or chickpea ${ }^{11,12}$ seeds have been mainly focused on globulins and albumins. Albumin separation from globulins has not always been successfully achieved owing to the intermediate solubility behaviors of some proteins. ${ }^{13}$ Several physicochemical methods have been developed for the fractionation of $7 \mathrm{~S}$ and $11 \mathrm{~S}$ proteins, including ultracentrifugation, fractionation and reverse phase high-performance liquid chromatography (HPLC); however, the yields and purities of isolated fractions were usually low, with cross-contamination among fractions being a main drawback. ${ }^{11,14}$ When the nutritional or functional properties of purified legume globulins have been evaluated, complex mixtures of $11 \mathrm{~S}$ and $7 \mathrm{~S}$ proteins have generally been used, and only a few nutritional studies with protein fractions have been reported so far. Given that $7 \mathrm{~S}$ and $11 \mathrm{~S}$ protein fractions differ in both protein composition and potential nutritional applications, it is clear that the establishment of a reliable protocol for fractionation of sufficient amounts of these proteins would open up novel opportunities to investigate the use of these fractions in preventive and/or therapeutic medicine.

In order to be tested in vivo and for their nutritional or physiological effects to be properly addressed, proteins from legume seeds have to be (1) extracted in sufficient amounts for their inclusion in diets for experimental animals and (2) chemically characterized so that their putative effects in vivo can be related to their chemical structure. Accordingly, pea ( $P$. sativum cv. Bilbo) seed meal was subjected to a chemical procedure to isolate and characterize its constituent albumins and globulins before these fractions are eventually utilized in in vivo trials.

\section{MATERIALS AND METHODS Materials}

Trypsin (type III) and $\alpha$-chymotrypsin (type VII) from bovine pancreas, $N$ - $\alpha$-benzoyl-DL-arginine- $p$-nitroanilide (BAPNA) and $N$ benzoyl-L-tyrosine ethyl ester (BTEE) were obtained from SigmaAldrich (Alcobendas, Spain).

\section{Fractionation procedures}

Peas ( $P$. sativum cv. Bilbo) were a gift from Limagrain UK Ltd (Rothwell, UK). Seeds were ground in a Retsch hammer mill (Biometa SA, Llanera, Spain) fitted with a $1 \mathrm{~mm}$ mesh screen. The meal was treated twice with chloroform/methanol (2:1 v/v) for lipid extraction and then air dried. The protein extraction procedure (Fig. 1) was as in Rubio et al. ${ }^{15}$ with some modifications. Defatted meal was extracted $(1: 10 \mathrm{w} / \mathrm{v})$ with $0.2 \mathrm{~mol} \mathrm{~L}^{-1}$ borate buffer $(\mathrm{pH} 8)$ containing $0.5 \mathrm{~mol} \mathrm{~L}^{-1} \mathrm{NaCl}$ and centrifuged (30 $074 \times$ g, $30 \mathrm{~min}, 4$ $\left.{ }^{\circ} \mathrm{C}\right)$. The supernatant was retained (supernatant A) and the borateinsoluble sediment was re-extracted as above and centrifuged. The new sediment (pea residue, PR) was recovered by freeze-drying. The extract (supernatant $B$ ) was combined with supernatant $A$, adjusted to $\mathrm{pH} 4.5$ with glacial acetic acid in the cold, stirred for 30 min and centrifuged $\left(30074 \times \mathrm{g}, 30 \mathrm{~min}, 4^{\circ} \mathrm{C}\right)$. The sediment was redissolved in borate buffer, dialysed extensively against distilled water and freeze-dried (legumins 11S). The supernatant was also dialysed extensively against distilled water and centrifuged (30 074 $\times g, 30 \mathrm{~min}, 4^{\circ} \mathrm{C}$ ). The new sediment was freeze-dried (vicilins $7 \mathrm{~S}$ ). The supernatant was treated with $608 \mathrm{~g} \mathrm{~L}^{-1}\left(\mathrm{NH}_{4}\right)_{2} \mathrm{SO}_{4}$, stirred for $2 \mathrm{~h}$ in the cold and centrifuged $\left(30074 \times \mathrm{g}, 30 \mathrm{~min}, 4^{\circ} \mathrm{C}\right)$. The sediment (albumins, Alb) was dialysed extensively against distilled water and freeze-dried. The supernatant containing mainly soluble non-starch polysaccharides (NSP) was also dialysed extensively against distilled water and freeze-dried. 


\section{Chemical analysis}

All analyses were performed in duplicate except for carbohydrates, which were run in triplicate. Nitrogen content was determined according to the Dumas procedure using a Truspec $\mathrm{CN}$ analyser (LECO Corporation, St Joseph, MI, USA). AA were determined, after protein hydrolysis in $6 \mathrm{~mol} \mathrm{~L}^{-1} \mathrm{HCl}$ plus $10 \mathrm{~g} \mathrm{~L}^{-1}$ phenol in sealed tubes at $110{ }^{\circ} \mathrm{C}$ for $24 \mathrm{~h}$, by HPLC according to the Waters Pico Tag method, ${ }^{16}$ using pre-column derivatization with phenylisothiocyanate and a Waters 2695 separation module (Waters Cromatografía SA, Madrid, Spain). A Millenium 32 chromatography manager system (Waters Cromatografía) was used for gradient control and data processing. Cysteine and methionine were determined as cysteic acid and methionine sulfone respectively, obtained by oxidation with performic acid before $6 \mathrm{~mol} \mathrm{~L}^{-1} \mathrm{HCl}$ hydrolysis. ${ }^{17}$ Tryptophan was not analysed. Starch (amyloglucosidase/ $\alpha$-amylase method, AOAC 996.11) was determined using a Megazyme K-TSTA analysis kit (Bray, Ireland). NSP analyses in feedstuffs and freeze-dried biological samples were carried out by gas/liquid chromatography. ${ }^{18}$ Concentrations of individual derivatized sugars were determined in a HewlettPackard (Avondale, PA, USA) gas chromatograph equipped with a flame ionization detector and fitted with a $30 \mathrm{~m} \times 0.25 \mathrm{~mm} \times 0.2$ $\mu \mathrm{m}$ Supelco SP 2380 capillary column (Bellefonte, PA, USA). ${ }^{19}$

\section{Protease inhibitory activity}

Pea seed meal and the albumin fraction were assessed for trypsin inhibitory activity (TIA) and chymotrypsin inhibitory activity (CIA). Finely ground samples $(50 \mathrm{mg}$ ) were extracted with $1.5 \mathrm{~mL}$ of $50 \mathrm{mmol} \mathrm{L}^{-1} \mathrm{HCl}$ at $4{ }^{\circ} \mathrm{C}$ for $2 \mathrm{~h}$ and centrifuged at $12000 \times \mathrm{g}$ for $10 \mathrm{~min}$ at room temperature. TIA was measured by means of a modified small-scale quantitative assay with BAPNA as specific substrate, using $50 \mathrm{mmol} \mathrm{L}^{-1}$ Tris ( $\mathrm{pH} 7.5$ ) instead of $0.01 \mathrm{~mol} \mathrm{~L}^{-1}$ $\mathrm{NaOH}$. One trypsin inhibitor unit (TIU) was defined as that which gives a reduction in absorbance at $410 \mathrm{~nm}$ of 0.01 , relative to trypsin control reactions, in a defined assay volume of $10 \mathrm{~mL} .{ }^{20} \mathrm{CIA}$ was measured using BTEE as specific substrate. One chymotrypsin inhibitor unit (CIU) was defined as that which gives a reduction in absorbance at $256 \mathrm{~nm}$ of 0.01 , relative to chymotrypsin control reactions, in a defined assay volume of $10 \mathrm{~mL} .^{21}$

\section{In vitro protein digestibility (IVPD)}

Pea seed proteins (legumins, vicilins and albumins) were digested in vitro as described previously ${ }^{22}$ by following the procedure described in Glahn et al. ${ }^{23}$ with some modifications. To verify the suitability of the method, casein and lactalbumin were included as control proteins in the assay. All analyses were performed in quadruplicate. Purified or control proteins $(30 \mathrm{mg}$ ) were suspended in $24 \mathrm{~mL}$ of $120 \mathrm{mmol} \mathrm{L}^{-1} \mathrm{NaCl}$. The $\mathrm{pH}$ was then adjusted to 10 with $0.1 \mathrm{~mol} \mathrm{~L}^{-1} \mathrm{NaOH}$, and samples were allowed to stand at room temperature for $15 \mathrm{~min}$. Aliquots $(50 \mu \mathrm{L})$ were taken from each tube to determine protein at time 0 . The $\mathrm{pH}$ was then adjusted to 2 with $5 \mathrm{~mol} \mathrm{~L}^{-1} \mathrm{HCl}$ and the volume was made up to $30 \mathrm{~mL}$ with $120 \mathrm{mmol} \mathrm{L}^{-1} \mathrm{NaCl}$ solution. For the gastric digestion step, $0.3 \mathrm{~mL}$ of pepsin solution ( $5 \mathrm{mg}$ in $2.5 \mathrm{~mL}$ of $0.1 \mathrm{~mol} \mathrm{~L}^{-1} \mathrm{HCl}$ ) was added to each sample, and tubes were placed in a shaker (100 oscillations $\min ^{-1}$ ) at $37^{\circ} \mathrm{C}$ for $1 \mathrm{~h}$. For the intestinal digestion step, the $\mathrm{pH}$ was raised to 6 with $1 \mathrm{~mol} \mathrm{~L}^{-1} \mathrm{NaHCO}_{3}$, and $7.5 \mathrm{~mL}$ of pancreatin/bile salt mixture ( $2.5 \mathrm{mg}$ of pancreatin and $15 \mathrm{mg}$ of bile extract in 25 $\mathrm{mL}$ of $100 \mathrm{mmol} \mathrm{L}^{-1} \mathrm{NaHCO}_{3}$ ) was added. The $\mathrm{pH}$ was adjusted to 7.5 with $1 \mathrm{~mol} \mathrm{~L}^{-1} \mathrm{NaOH}$ and the volume was made up to 45 $\mathrm{mL}$ with $120 \mathrm{mmol} \mathrm{L}^{-1} \mathrm{NaCl}$. Intestinal digestion of proteins was

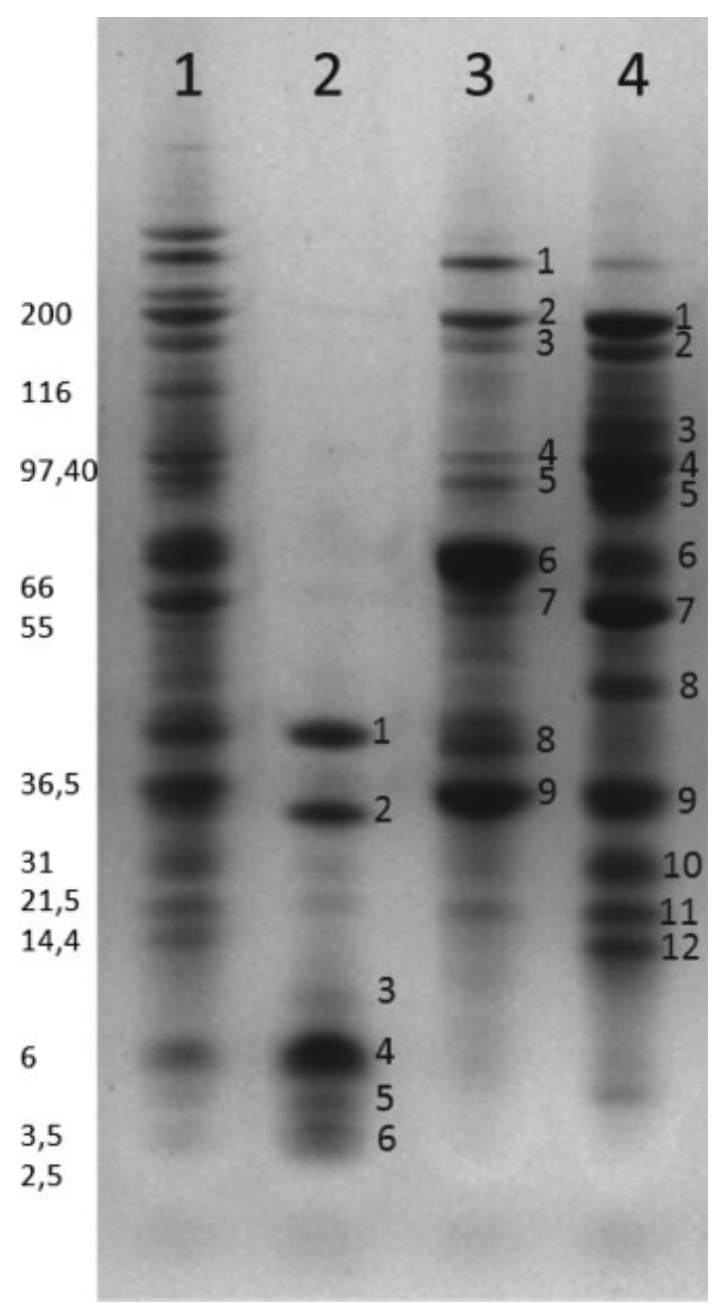

Figure 2. SDS-PAGE of extracted pea (Pisum sativum cv. Bilbo) protein fractions: lane 1, defatted pea seed meal; lane 2, albumin fraction; lane 3, legumin (11S) fraction; lane 4, vicilin (7S) fraction. For band identification and relative amounts, see Table 1 .

carried out at $37^{\circ} \mathrm{C}$ for $2 \mathrm{~h}$. Controls containing only the digestive enzymes in buffered solution were included in the assay. After protein digestion, enzymes were inactivated by heating at $85^{\circ} \mathrm{C}$ for $5 \mathrm{~min}$ in a water bath. Tubes were allowed to stand for $5 \mathrm{~min}$ on ice and centrifuged at $12000 \times g$ for $10 \mathrm{~min}$ at $4{ }^{\circ} \mathrm{C}$. Aliquots $(5 \mathrm{~mL})$ of the supernatant were concentrated in a CentriVap concentrator (Labconco Corporation, Kansas City, MO, USA), and total N was determined according to the Dumas procedure using a Truspec $\mathrm{CN}$ analyser (LECO Corporation). Digested protein was considered as that soluble in $100 \mathrm{~g} \mathrm{~L}^{-1}$ trichloroacetic acid (TCA). IVPD was calculated as follows: $\mathrm{N}(\mathrm{mg})$ soluble in $100 \mathrm{~g} \mathrm{~L}^{-1}$ TCA after digestion/total amount $(\mathrm{mg})$ of $\mathrm{N}$ initially added.

\section{Sodium dodecyl sulfate polyacrylamide gel electrophoresis (SDS-PAGE) analysis}

SDS-PAGE analysis was carried out to monitor the electrophoretic pattern of the different protein extracts. Samples containing 1 mg protein $\mathrm{mL}^{-1}(32.5 \mu \mathrm{L})$ were mixed with $5 \mu \mathrm{L}$ of $0.5 \mathrm{~mol} \mathrm{~L}^{-1}$ dithiothreitol (DTT) and $12.5 \mu \mathrm{L}$ of NuPAGE ${ }^{\circledR}$ LDS sample buffer $(4 \times)$ (Invitrogen, Barcelona, Spain). Aliquots of $20 \mu \mathrm{L}$ were loaded onto the gel. Separation was performed on 4-12\% linear gradient polyacrylamide NuPAGE ${ }^{\circledR}$ Novex Bis-Tris precast gels using a 
Table 1. Putative identification by mass peptide fingerprinting and amount (\%) of different proteins in each protein lane (lane 2, albumins; lane 3 , legumins 11S; lane 4, vicilins 7S) extracted from defatted pea seed meal

\begin{tabular}{|c|c|c|c|c|c|}
\hline $\begin{array}{l}\text { Electrophoretic } \\
\text { band }\end{array}$ & $\%$ of protein in lane $\mathrm{e}^{\mathrm{a}}$ & Homologous protein & Mascot score ${ }^{b}$ & $\begin{array}{c}\text { Protein sequence } \\
\text { coverage (\%) }\end{array}$ & $\begin{array}{c}\text { UniProtKB/Swiss-Prot } \\
\text { Accession No. }\end{array}$ \\
\hline 2.1 & 17.4 & Pea albumin 2 (PA2) & 214 & 67 & P08688 \\
\hline 2.2 & 17.3 & Pea albumin 2 (PA2) & 89 & 42 & P08688 \\
\hline 2.3 & 12.6 & Bowman-Birk inhibitors $^{c}$ & & & \\
\hline 2.4 & 24.5 & Pea albumin 2 (PA2) & 58 & 26 & P08688 \\
\hline 2.5 & 13.4 & Defensins 1 and 2 & 57 and 54 & 80 and 72 & P81929 \\
\hline 2.6 & 14.8 & Pea albumin 2 (PA2) & 47 & 8 & P08688 \\
\hline 3.1 & 4.3 & Convicilin & 28 & 18 & P13915 \\
\hline 3.2 & 5.3 & Convicilin & 113 & 25 & P13915 \\
\hline 3.3 & 4.2 & Convicilin & 131 & 32 & P13915 \\
\hline 3.4 & 3.9 & Vicilin & 123 & 30 & P13918 \\
\hline 3.5 & 6.6 & Provicilin & 38 & 28 & P02855 \\
\hline 3.6 & 24.9 & Legumin & 119 & 26 & P15838 \\
\hline 3.7 & 6.9 & Legumin & 44 & 16 & P15838 \\
\hline 3.8 & 17.7 & Pea albumin 2 & 111 & 51 & P08688 \\
\hline 3.9 & 26.2 & Legumin & 88 & 28 & P15838 \\
\hline 4.1 & 7.0 & Convicilin & 165 & 29 & P13915 \\
\hline 4.2 & 5.1 & Convicilin & 225 & 39 & P13915 \\
\hline 4.3 & 5.7 & Convicilin & 201 & 37 & P13915 \\
\hline 4.4 & 7.4 & Vicilin & 291 & 60 & P13918 \\
\hline 4.5 & 7.7 & Vicilin & 119 & 31 & P13918 \\
\hline 4.6 & 8.7 & Mixture of vicilin and convicilin & 68 and 62 & 25 and 22 & P13918, P13915 \\
\hline 4.7 & 12.5 & Provicilin & 130 & 34 & P02854 \\
\hline 4.8 & 7.2 & Vicilin & 122 & 33 & P13918 \\
\hline 4.9 & 14.2 & Vicilin & 82 & 24 & P13918 \\
\hline 4.10 & 10 & Provicilin & 70 & 23 & P02854 \\
\hline 4.11 & 7.6 & Provicilin & 78 & 21 & P02854 \\
\hline 4.12 & 6.9 & Provicilin & 90 & 25 & P02854 \\
\hline
\end{tabular}

continuous buffer system (NuPAGE ${ }^{\circledR}$ MES SDS running buffer, Invitrogen) for $50 \mathrm{~min}$ at a constant voltage of $200 \mathrm{~V}$. Unstained protein molecular markers (Mark $12^{\mathrm{TM}}$, Invitrogen) were applied to the gel. Electrophoretic bands were stained with a Coomassie Blue staining kit (Invitrogen), and the electrophoretic pattern was analysed using Quantity One software (Bio-Rad, Madrid, Spain).

\section{Protein identification by mass peptide fingerprinting}

After staining, visualized electrophoretic bands with proteins of interest were excised using an EXQuest spot cutter (Bio-Rad) and digested using a DigestPro MS (Intavis AG, Valencia, Spain). Proteins were reduced with $10 \mathrm{mmol} \mathrm{L}^{-1}$ DTT (Sigma-Aldrich) for 45 min at $56{ }^{\circ} \mathrm{C}$, alkylated with $55 \mathrm{mmol} \mathrm{L}^{-1}$ iodoacetamide (SigmaAldrich) for $30 \mathrm{~min}$ in the dark at laboratory temperature and digested with $15 \mu \mathrm{L}$ of $10 \mathrm{ng} \mu \mathrm{L}^{-1}$ trypsin (Promega, Alcobendas, Spain) for $4 \mathrm{~h}$ at $37{ }^{\circ} \mathrm{C}$. Peptides were extracted from the gel with $40 \mu \mathrm{L}$ of $2 \mathrm{~g} \mathrm{~L}^{-1}$ trifluoroacetic acid (TFA), $20 \mu \mathrm{L}$ of 50 mmol $\mathrm{L}^{-1}$ ammonium bicarbonate and $20 \mu \mathrm{L}$ of acetonitrile and concentrated under vacuum centrifugation to a final volume of 10-15 $\mu \mathrm{L}$. Samples were passed through a ZipTip $\mu$-C18 column (Millipore, Madrid, Spain) using a DigestPro MS (Intavis AG). The ZipTip was previously treated with acetonitrile and $2 \mathrm{~g} \mathrm{~L}^{-1}$ TFA, and peptides were eluted with $600 \mathrm{~mL} \mathrm{~L}^{-1}$ acetonitrile/2 $\mathrm{g} \mathrm{L}^{-1}$
TFA. Samples were crystallized in the analysis plaques with a CHCA matrix (LaserBio Labs, Sophia-Antipolis, France). Matrix-assisted laser desorption/ionization time-of-flight (MALDI-TOF) analysis of the tryptic digests was carried out with a Voyager DE-PRO mass spectrometer (Applied Biosystems, Alcobendas, Spain). Spectra were calibrated internally using the peptidic molecular weights of the trypsin digestion or with external standards. The identification of proteins from the peptidic molecular weights was carried out through the $\mathrm{NCBI}$ and Swiss-Prot databases using the Mascot search engine (Matrix Science, London, UK).

\section{RESULTS AND DISCUSSION}

\section{Fractionation procedures}

The rationale behind the isolation of the different fractions by this procedure was the differences in solubility (water for albumins and salt solutions for globulins) and in isoelectric points between legumins and vicilins. ${ }^{24}$ About $70.7 \mathrm{~g} \mathrm{~kg}^{-1}$ was extracted as globulin material from defatted pea ( $P$. sativum cv. Bilbo) meal, of which $40.6 \mathrm{~g} \mathrm{~kg}^{-1}$ corresponded to $7 \mathrm{~S}$ vicilins and $30.1 \mathrm{~g}$ $\mathrm{kg}^{-1}$ to $11 \mathrm{~S}$ legumins. In previous studies, ${ }^{15,25}$ where we used a similar protein extraction procedure on a small scale, the yield was higher (about $160 \mathrm{~g} \mathrm{~kg}^{-1}$ as globulin material from lupin and faba 
bean seed meals). In the present work we have used a large-scale extraction procedure starting with $9 \mathrm{~kg}$ of defatted seed meal. Crévieu et al., ${ }^{26}$ using a different large-scale procedure, obtained about $1000 \mathrm{~g}$ of globulin fraction from $15 \mathrm{~kg}$ of pea flour, which represents $66.7 \mathrm{~g} \mathrm{~kg}^{-1}$, a value closer to that obtained here. For the albumin fraction we obtained $21.3 \mathrm{~g} \mathrm{~kg}^{-1}$, while Crévieu et al. ${ }^{26}$ reported a yield of $25.3 \mathrm{~g} \mathrm{~kg}^{-1}$ flour. Protein content in different varieties is also known to be variable, and a positive relationship between protein content and legumin/vicilin ratio in pea seeds has recently been reported. ${ }^{27}$

Electrophoretic profiling of the three major protein fractions (11S, 7S and albumins) (Fig. 2) and putative identification of their major components by mass peptide fingerprinting (Table 1) were carried out. Data analysis demonstrated a lack of crosscontamination in the vicilin and albumin fractions, but not in the legumin fractionm, where vicilins and albumins were also detected. As expected, the $7 \mathrm{~S}$ fraction showed major electrophoretic bands corresponding to vicilin and convicilin polypeptides, the latter being of higher relative mobility $(\mathrm{Mr})(\geq 70 \mathrm{kDa}$ ). Polypeptides of $\mathrm{Mr}$ lower than $50 \mathrm{kDa}$ have been reported to be derived from vicilin precursors by limited post-translational processing. ${ }^{28}$ In the albumin fraction the major identified proteins were pea albumin 2 (PA2), defensins 1 and 2 and Bowman-Birk inhibitors $(\mathrm{BBI})$. In the case of $\mathrm{BBI}$, the search for peptide mass data for protein identification against databases was unsuccessful. This could be due to the presence of several BBI isoforms with sequence variation, which can make putative identification more difficult. ${ }^{29}$ Further attempts to identify pea $\mathrm{BBI}$ isoforms were carried out. After trypsin digestion, electrophoretic band 3 of the albumin fraction (Fig. 2) showed peptides with molecular masses of 1693.6920 and $2256.8777 \mathrm{Da}$, which matched those derived from in silico trypsin digestion of TI1 (accession number Q9M3X3P from Uni-Prot KB/TrEMBL), a major pea isoinhibitor described previously; an additional peptide mass, $3805 \mathrm{Da}$, could be associated with TI2 (accession number Q41066), another major pea isoinhibitor. ${ }^{21}$ The $11 \mathrm{~S}$ fraction consisted of a heterogeneous mixture of relatively impure polypeptides with the presence of vicilin, convicilin and PA2, representing 104,95 and $170 \mathrm{~g} \mathrm{~kg}^{-1}$ total protein respectively. A major electrophoretic band corresponding to acidic polypeptides of legumins ( $\sim 40 \mathrm{kDa} ; 26.2 \%$ of total protein) was detected.

\section{Chemical analysis}

Despite the present interest in pea seed as a protein source, particularly in animal nutrition, not much information can be found in the literature concerning its carbohydrate composition. In addition, where found, information from animal studies usually refers to neutral and acid detergent fibre analysis. ${ }^{30,31}$ Total free sugars, including oligosaccharides, were not analysed here, because they are soluble in water and lost through dialysis and therefore not likely to be found in the protein fractions, which are the main interest of the designed procedure. The values determined here (Table 2) for NSP content and composition of pea seed meal were similar to those reported previously. ${ }^{32-34}$ Uronic acids, glucose (mainly as cellulose) and arabinose were the most abundant constituent sugars. The extracted protein fractions (legumins, vicilins and albumins) contained between 56.7 and 67.7 g NSP kg ${ }^{-1}$, probably deriving mostly from the soluble NSP fraction, which constitutes about $52 \mathrm{~g} \mathrm{~kg}^{-1}$ in pea seed meal, ${ }^{32}$ and also from the carbohydrate fraction of the proteins themselves. A small amount of starch $\left(0.3-35.7 \mathrm{~g} \mathrm{~kg}^{-1}\right)$ was also determined in the protein fractions. The carbohydrate fraction therefore amounted to between 68.0 and $98.3 \mathrm{~g} \mathrm{~kg}^{-1}$ extracted proteins, with vicilins containing the lowest amount.

The total protein content and AA composition of pea seed meal and its fractions are shown in Table 3. Bibliographic information on AA composition is greater than it is on carbohydrates, and it is generally known that a low content of essential AA such as sulfur-containing AA limits the nutritive value of many food proteins of plant origin, such as soybean and other legumes, including pea. ${ }^{3}$ In pea meal, lysine, arginine and leucine were the most abundant among the essential AA, while aspartic acid and glutamic acid were the most abundant among the non-essential AA, which is in agreement with a previous report. ${ }^{35}$ However, much less information exists on the AA composition of legume seed proteins and protein fractions. The composition of AA in pea proteins ultimately depends on the proportion of the three major soluble protein fractions present in pea seeds: legumins, vicilins and albumins. According to Owusu-Ansah and McCurdy (1991), as cited by Urbaityte et al., ${ }^{36}$ legumin contains more sulfur-containing AA and arginine, whereas vicilin is enriched in isoleucine, leucine, phenylalanine and lysine. This is relevant, as these are essential AA. Also, in another of the few reports on this issue, Croy et al. ${ }^{37}$ reported that the most abundant $A A$ in vicilins are glutamate, aspartate, leucine and lysine. These previous reports are in line with values obtained here. In the case of the AA composition of pea albumins, there are even fewer reports. Croy et al..$^{38}$ reported that total albumin proteins obtained by extraction with sodium acetate buffer ( $\mathrm{pH}$ 5) and chromatography through Sephadex G-150 and DE-cellulose columns were high in aspartic acid, glutamic acid, glycine, alanine, valine and lysine. In the present study the most abundant AA in the albumin fraction were aspartic acid, glutamic acid, lysine and arginine, and the amounts of methionine were more than double than those in legumins and vicilins.

\section{Protease inhibitor activity}

The cv. Bilbo showed relatively low TIA and CIA, with $1.8 \pm 0.1$ TIU and $1.4 \pm 0.2 \mathrm{CIU} \mathrm{mg}^{-1}$ dry weight. In a previous study, several pea genotypes were screened for their relative TIA and

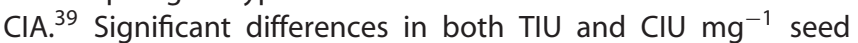
meal were found among pea genotypes, ranging from 4.1 to 10.7 TIU $\mathrm{mg}^{-1}$ and from 5.3 to $11.1 \mathrm{CIU} \mathrm{mg}^{-1}$. The pea albumin fraction showed a clear enrichment of protease inhibitory activity compared with the seed meal, with values of $56.7 \pm 0.5$ TIU

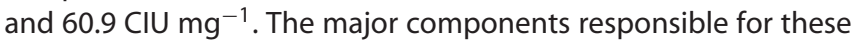
increased inhibitory activities are the water-soluble BBI. Emerging evidence suggests that BBI exert their potential chemopreventive and therapeutic properties via protease inhibition. ${ }^{40}$ In previous studies a significant concentration- and time-dependent decrease in the growth of an array of colon cancer cells (HT29, Caco2 and LoVo) has been demonstrated in vitro following treatment with $\mathrm{BBI}$ variants from several legume sources, including pea, ${ }^{40}$ lentil $^{41}$ and soybean. ${ }^{42}$ The cytotoxic effect of BBI isoforms from soybean on HT29 human colorectal cancer cells is related to their intrinsic ability to inhibit serine proteases. In contrast, the growth of non-malignant colonic fibroblastic CCD18-Co cells was unaffected by BBI. Recently, the antiproliferative effect of rTI1B, a major pea isoinhibitor expressed heterologously in Pichia pastoris, has been evaluated using colon cancer cells grown in vitro. ${ }^{40}$ Comparisons of the effects of rTI1B with those observed using a related synthetic mutant derivative showed that the proliferation of HT29 colon cancer cells was inhibited significantly by rTI1B in a dose-dependent manner, whereas the mutant that lacked trypsin 
Table 2. Non-starch polysaccharide (NSP) composition and starch content ( $\mathrm{g} \mathrm{kg}^{-1}$ dry matter) of pea (Pisum sativum cv. Bilbo) seed meal and its protein fractions

\begin{tabular}{|c|c|c|c|c|c|c|}
\hline Component & Meal & Defatted meal & Legumins & Vicilins & Albumins & Residue $^{a}$ \\
\hline Rhamnose & 4.9 & 4.8 & 4.5 & 4.4 & 0.0 & 7.0 \\
\hline Arabinose & 17.1 & 17.8 & 3.7 & 11.7 & 4.4 & 18.9 \\
\hline Xylose & 8.6 & 10.2 & 0.0 & 7.3 & 3.1 & 8.7 \\
\hline Mannose & 10.2 & 9.4 & 9.4 & 9.2 & 10.4 & 9.2 \\
\hline Galactose & 10.8 & 13.1 & 15.0 & 9.3 & 16.0 & 9.6 \\
\hline Glucose & 48.6 & 69.3 & 19.4 & 21.9 & 19.4 & 70.6 \\
\hline Uronic acids & 46.7 & 45.3 & 10.6 & 4.1 & 3.5 & 47.1 \\
\hline Total NSP & 146.9 & 169.9 & 62.6 & 67.7 & 56.7 & 171.0 \\
\hline Starch & 373.2 & 397.9 & 35.7 & 0.3 & 32.1 & 602.3 \\
\hline
\end{tabular}

a See Fig. 1.

Table 3. Nitrogen ( $\mathrm{N}$ ) content and amino acid composition ( $\mathrm{g} \mathrm{kg}^{-1}$ dry matter) of pea (Pisum sativum cv. Bilbo) seed meal and its protein fractions

\begin{tabular}{|c|c|c|c|c|c|c|}
\hline Component & Meal & Defatted meal & Legumins & Vicilins & Albumins & Residue $^{a}$ \\
\hline Total N & 40.0 & 41.4 & 138.9 & 160.8 & 145.3 & 14.5 \\
\hline Protein $(\mathrm{N} \times 5.6)^{\mathrm{b}}$ & 224.0 & 231.7 & 778.0 & 900.0 & 813.7 & 81.0 \\
\hline \multicolumn{7}{|c|}{ Essential amino acids } \\
\hline Methionine & 5.8 & 6.0 & 9.7 & 6.9 & 17.9 & 1.06 \\
\hline Cystine & 0.0 & 0.0 & 0.1 & 0.1 & 0.1 & 0.01 \\
\hline Lysine & 19.1 & 20.2 & 50.1 & 111.3 & 101.4 & 6.68 \\
\hline Histidine & 8.6 & 9.6 & 23.6 & 32.1 & 36.1 & 3.03 \\
\hline Arginine & 13.4 & 16.5 & 30.2 & 41.4 & 84.5 & 4.17 \\
\hline Tyrosine & 8.8 & 9.5 & 26.4 & 35.0 & 39.0 & 4.53 \\
\hline Leucine & 13.4 & 15.8 & 49.1 & 86.9 & 34.6 & 5.64 \\
\hline Isoleucine & 7.8 & 9.5 & 25.4 & 41.8 & 28.3 & 3.43 \\
\hline Threonine & 14.2 & 16.0 & 50.4 & 63.6 & 44.2 & 7.24 \\
\hline Valine & 8.8 & 10.4 & 29.7 & 39.2 & 36.4 & 4.56 \\
\hline Phenylalanine & 9.7 & 10.7 & 30.4 & 54.7 & 30.6 & 3.79 \\
\hline \multicolumn{7}{|c|}{ Non-essential amino acids } \\
\hline Aspartate & 25.8 & 34.3 & 87.4 & 151.4 & 130.1 & 8.20 \\
\hline Glutamate & 34.1 & 40.9 & 126.3 & 204.7 & 154.0 & 9.70 \\
\hline Serine & 10.8 & 12.5 & 34.7 & 55.4 & 44.2 & 4.16 \\
\hline Glycine & 9.8 & 11.0 & 27.4 & 33.3 & 56.7 & 4.06 \\
\hline Alanine & 8.4 & 10.2 & 25.7 & 31.3 & 51.3 & 3.39 \\
\hline Proline & 13.5 & 13.7 & 39.4 & 49.2 & 45.0 & 8.32 \\
\hline
\end{tabular}

and chymotrypsin inhibitory activity did not show any significant effect on colon cancer cell growth.

\section{In vitro protein digestibility}

As shown in Table 4, digestibility values for pea proteins $(0.63 \pm$ $0.04,0.88 \pm 0.04$ and $0.41 \pm 0.23$ for legumins, vicilins and albumins respectively) were similar or even numerically higher than those for control proteins $(0.48 \pm 0.05$ and $0.73 \pm 0.23$ for lactalbumin and casein respectively). This is in agreement with previous in vitro ${ }^{43}$ and in vivo ${ }^{25}$ studies. It is generally thought that the presence of antinutritional factors (ANF) together with the slower digestion rate of legume proteins compared with animal proteins could explain the lower nutritional efficiency of legume proteins in vivo. Nevertheless, this conclusion is mostly based on experiments in which the whole seed meal was used in the diet. Where purified proteins were tested, only in vitro values were usually reported. One of the few reports on in vivo digestibility studies with purified proteins is that by Aubry and Boucrot, ${ }^{44}$ who showed that, after $2 \mathrm{~h}$ of gastric emptying, the intestinal absorption of pea vicilin and legumin in rats was as high as that of casein. However, the nutritional value (measured as protein efficiency ratio and biological value) of diets based on purified legume proteins or even seed meals containing low amounts of or no ANF is below that of control diets, even though both fecal and ileal digestibilities of globulins purified from legume seeds such as soya bean (G. max), faba bean (Vicia faba) and narrowleafed lupin (Lupinus angustifolius) were not different from control values in the rat. ${ }^{15,45}$ Furthermore, ileal and fecal $\mathrm{N}$ digestibilities of whole legume seed meals low in ANF are usually similar or close to control values. ${ }^{25,46,47}$ These results suggest that undenatured legume globulins are highly digestible in the small intestine, so the lower digestibility of legume proteins when the whole meal is used 
Table 4. In vitro protein digestibility of lactalbumin, casein and purified pea (Pisum sativum cv. Bilbo) seed protein fractions

Protein or seed protein fraction In vitro protein digestibility ${ }^{\text {a }}$

Lactalbumin

$0.48 \pm 0.05$

Casein

$0.73 \pm 0.23$

Legumins

$0.63 \pm 0.04$

Vicilins

$0.88 \pm 0.04$

Albumins

$0.41 \pm 0.23$

a Values are mean \pm standard deviation

in the diet is likely to be due to other factors such as lectins, tannins and/or trypsin inhibitors. However, feeding growing animals with diets based on legume seed meals as the main source of protein results in performance values that are lower than expected based on the chemical composition of the diets. Previous results ${ }^{48,49}$ suggest that AA from legume protein isolates are absorbed at slower rates than those from animal proteins, which might explain the lower nutritional utilization of legume storage proteins as compared with lactalbumin or casein.

\section{CONCLUSIONS}

Very little information is at present available in the literature on the chemical characterization of legumes, particularly pea seed fractions. Even less information exists on the composition of constituent protein fractions, particularly vicilins. This is very relevant in order to properly link the nutritional effects of a given component with its chemical properties. By the procedure here described, vicilin and albumin fractions devoid of crosscontamination with other proteins were obtained from pea ( $P$. sativum cv. Bilbo) seed meal. The legumin fraction consisted of a heterogeneous mixture of relatively impure polypeptides. The extracted protein fractions (legumins, vicilins and albumins) contained between 56.7 and $67.7 \mathrm{~g} \mathrm{NSP} \mathrm{kg}^{-1}$, probably deriving mostly from the soluble NSP fraction, with vicilins containing the lowest amount. Legumins contained more sulfur-containing AA and arginine, whereas vicilins were enriched in isoleucine, leucine, phenylalanine and lysine. The pea albumin fraction showed a clear enrichment of protease inhibitory activity when compared with the seed meal. In vitro digestibility values for pea proteins were similar to or even numerically higher than those for control proteins.

\section{ACKNOWLEDGEMENTS}

This work was carried out with financial support from the Spanish MICIIN (PET2008-0311) and from ABBOTT Laboratories S.A. This research has also been partially supported by FEDER and FSE funds from the European Union. $A C$ is involved in COST Action FA1005 Infogest Food Digestion and acknowledges support by ERDF-cofinanced grant from the Spanish CICyT (AGL2011-26353). The authors are very grateful to the Proteomics Facility Services of the Institute of Parasitology and Biomedicine Lopez-Neyra (Granada, Spain) for peptide mass fingerprinting analysis.

\section{REFERENCES}

1 Kostyra H, Food proteins - evolution and nutritional aspects, in Effects of Antinutrients on the Nutritional Value of Legume Diets. COST 98, Vol. 1, ed. by Bardocz S, Gelencsér E and Pusztai A. European Commission Directorate-General XII, Brussels, pp. 86-89 (1996).

2 Clemente A, Enzymatic protein hydrolysates in human nutrition. Trends Food Sci Technol 11:254-262 (2000).

3 Friedman M, Nutritional value of proteins from different food sources. A review. J Agric Food Chem 44:6-29 (1996).

4 Duranti M, Grain legume proteins and nutraceutical properties. Fitoterapia 77:67-82 (2006).

5 European Commission Council Regulation of 28 June 2007 on organic production and labelling of organics products and repealing Regulation (EEC) N 2092/91. Off J Eur Union L189:1-23 (2007).

6 Vankosky MA, Cárcamo HA, McKenzie RH and Dosdall LM, Integrated management of Sitona lineatus with nitrogen fertilizer, Rhizobium, and thiamethoxam insecticide. Agron J 103:565-572 (2011).

7 Leterme $P$, Recommendations by health organizations for legume consumption. Br J Nutr 88:239-242 (2002).

8 Danielsson CE, Seed globulins of the Gramineae and Leguminosae. Biochem J 44:387-400 (1949).

9 Guéguen J and Cerletti P, Proteins of some legume seeds, soybean, pea, faba bean and lupin, in New and Developing Sources of Food Proteins, ed. by Hudson BJF. Chapman and Hall, New York, NY, pp. 145-183 (1994).

10 Crevieu I, Berot S and Gueguen J, Large scale procedure for fractionation of albumins and globulins from pea seeds. Nahrung 40:237-244 (1996).

11 Clemente A, Sánchez-Vioque R, Vioque J, Bautista J and Millán F, Effect of cooking on protein quality of chickpea seeds. Food Chem 62:1-6 (1998).

12 Liu C, Wang H, Cui Z, He X, Wang X, Zeng X, et al, Optimization of extraction and isolation for $11 S$ and $7 S$ globulins of soybean seed storage protein. Food Chem 102:1310-1316 (2007).

13 Franco E, Ferreira RB and Texeira AR, Utilization of an improved methodology to isolate Lupinus albus conglutins in the study of their sedimentation coefficients. J Agric Food Chem 45:3908-3913 (1997).

14 Liu LH, Hung TV and Bennett L, Extraction and characterization of chickpea (Cicer arietinum) albumin and globulin. J Food Sci 73:299-305 (2008).

15 Rubio LA, Grant G, Daguid T, Brown D, Bardocz S and Pusztai A, The nutritional utilization by rats of chickpea (Cicer arietinum) meal and its isolated globulin proteins is poorer than that of defatted soybean or lactalbumin. J Nutr 128:1042-1047 (1998).

16 Cohen SA, Meys M and Tarvin TL, The Pico Tag Method. A Manual of Advanced Techniques for Amino Acid Analysis. Millipore Corporation, Bedford, MA (1989).

17 Moore S, On the determination of cystine as cysteic acid. J Biol Chem 238:235-237 (1963).

18 Englyst HN, Quigley ME, Hudson GJ and Cummings JH, Determination of dietary fiber as non-starch polysaccharides by GLC chromatography. Analyst 117:1707-1714 (1982).

19 Rubio LA, Pedrosa MM, Pérez A, Cuadrado C, Burbano C and Muzquiz $M$, lleal digestibility of defatted soybean, lupin and chickpea seed meals in cannulated Iberian pigs: II. Fatty acids and carbohydrates. J Agric Food Chem 85:1322-1328 (2005).

20 Domoney $C$ and Welham T, Trypsin inhibitors in Pisum: variation in amount and pattern of accumulation in developing seed. Seed Sci Res 2:147-154 (1992).

21 Clemente A, MacKenzie DA, Jeenes DJ and Domoney C, The effect of variation within inhibitory domains on the activity of pea protease inhibitors from the Bowman-Birk class. Protein Expr Purif 36:106-114 (2004).

22 Moreno FJ, Rubio LA, Olano A and Clemente A, Uptake of $2 S$ albumin allergens, Ber e 1 and Ses i 1, across human intestinal epithelial Caco-2 cell monolayers. J Agric Food Chem 54:8631-8639 (2006).

23 Glahn RP, Wien EM, Van Campen DR and Miller DD, Caco-2 cell iron uptake from meat and casein digests parallels in vivo studies: use of a novel in vitro method for rapid estimation of iron bioavailability. $J$ Nutr 126:332-339 (1996).

24 Derbyshire $E$, Wright $D J$ and Boulter $D$, Legumin and vicilin, storage proteins of legume seeds. Phytochemistry 15:3-24 (1976).

25 Rubio LA, Grant G, Cavallé C, Martinez-Aragón A and Pusztai A, High in vivo (rat) digestibility of faba bean (Vicia faba), lupin (Lupinus angustifolius) and soybean (Glycine max) soluble globulins. J Sci Food Agric 66:289-292 (1994). 
26 Crévieu I, Bérot S and Guéguen J, Large scale procedure for fractionation of albumins and globulins from pea seeds. Nahrung 40:237-244 (1994).

27 Mertens C, Dehon L, Bourgeois A, Verhaeghe-Cartrysse C and Blecker C, Agronomical factors influencing the legumin/vicilin ratio in pea (Pisum sativum L.) seeds. J Sci Food Agric 92:1591-1596 (2012).

28 Gatehouse JA, Croy RRD, Morton H, Tyler M and Boulter D, Characterization and subunit structures of the vicilin storage proteins of pea (Pisum sativum L.). Eur J Biochem 118:627-633 (1981).

29 Clemente A and Domoney C, Biological significance of polymorphism in plant protease inhibitors from the Bowman-Birk class. Curr Protein Pept Sci 7:201 - 216 (2006).

30 Salgado P, Martins JM, Carvalho F, Abreu M, Freire JPB, Toullec R, et al, Component digestibility of lupin (Lupinus angustifolius) and pea (Pisum sativum) seeds and effects on the small intestine and body organs in anastomosed and intact growing pigs. Anim Feed Sci Technol 98:187-201 (2002).

31 Prandini A, Sigolo S, Morlacchini M, Cerioli C and Masoero F, Pea (Pisum sativum) and faba bean (Vicia faba L.) seeds as protein sources in growing-finishing heavy pig diets: effect on growth performance, carcass characteristics and on fresh and seasoned Parma ham quality. Ital J Anim Sci 10:176-183 (2011).

32 Bach Knudsen KE, Carbohydrate and lignin contents of plant materials used in animal feeding. Anim Feed Sci Technol 67:319-338 (1997).

33 Canibe N and Bach Knudsen KE, Digestibility of dried and toasted peas in pigs. 1. Ileal and total tract digestibilities of carbohydrates. Anim Feed Sci Technol 64:293-310 (1997).

34 Alonso R, Rubio LA, Muzquiz M and Marzo F, The effect of extrusion cooking on mineral availability in peas and kidney bean seed meals. Anim Feed Sci Technol 92:1 -13 (2001).

35 Mariscal-Landín G, Lebreton Y and Sève B, Apparent and standardized true ileal digestibility of protein and amino acids from faba bean, lupin and pea, provided as whole seeds, dehulled or extruded in pig diets. Anim Feed Sci Technol 97:183-198 (2002).

36 Urbaityte R, Mosenthin R and Eklund M, The concept of standardized ileal amino acid digestibilities: principles and application in feed ingredients for piglets. Asian Aust J Anim Sci 22:1209-1223 (2009).

37 Croy RD, Hoque MS, Gatehouse JA and Boulter D, The purification and characterization of a third storage protein (convicilin) from the seeds of pea (Pisum sativum L.). Biochem J 191:509-516 (1980).

38 Croy RD, Hoque MS, Gatehouse JA and Boulter D, The major albumin proteins from pea (Pisum sativum L). Purification and some properties. Biochem J 218:795-803 (1984).

39 Clemente A, Gee JM, Johnson IT, MacKenzie DA and Domoney C, Pea (Pisum sativum L.) protease inhibitors from the Bowman-Birk class influence the growth of human colorectal adenocarcinoma HT29 cells in vitro. J Agric Food Chem 53:8979-8986 (2005).
40 Clemente A, Marín-Manzano MC, Jiménez E, Arqués MC and Domoney C, The anti-proliferative effects of TI1B, a major Bowman-Birk isoinhibitor from pea (Pisum sativum L), on HT29 colon cancer cells are mediated through protease inhibition. Br J Nutr 108:S135-S144 (2012).

41 Caccialupi P, Ceci LR, Siciliano RA, Pignone D, Clemente A and Sonnante G, Bowman-Birk inhibitors in lentil: heterologous expression, functional characterisation and anti-proliferative properties in human colon cancer cells. Food Chem 120:1058-1066 (2010).

42 Clemente A, Moreno FJ, Marín-Manzano MC, Jiménez E and Domoney $C$, The cytotoxic effect of Bowman-Birk isoinhibitors, IBB1 and IBBD2, from soybean (Glycine max) on HT29 human colorectal cancer cells is related to their intrinsic ability to inhibit serine proteases. Mol Nutr Food Res 54:396-405 (2010).

43 Rubio LA and Seiquer I, Transport of amino acids from in vitro digested legume proteins or casein in Caco-2 cell cultures. J Agric Food Chem 50:5202-5207 (2002).

44 Aubry $\mathrm{M}$ and Boucrot $\mathrm{P}$, Etude comparée de la digestion des viciline, legumine et lectine radiomarquées de Pisum sativum chez le rat. Ann Nutr Metabol 30:175-182 (1986).

45 Rubio LA, Grant G, Bardocz S, Dewey P and Pusztai A, Nutritional response of growing rats to faba beans (Vicia faba) and faba bean fractions. Br J Nutr 66:533-542 (1991).

46 Rubio LA, Grant G, Scislowsky P, Brown D, Annand M and Pusztai A, The utilization of lupin and faba bean globulins by rats is poorer than of soybean globulins or lactalbumin but the nutritional value of lupin seed meal is lower only than that of lactalbumin. $J$ Nutr 125:2145-2155 (1995).

47 Van der Poel AFB, Dellaert LM, Norel A and van Helpster JPFG, The digestibility in piglets of faba bean (Vicia faba L.) as affected by breeding towards the absence of condensed tannins. Br J Nutr 68:793-800 (1992).

48 Rubio LA, Rodríguez J, Fernández C and Crespo JF, Storage proteins: physiological and antigenic effects, in Recent Advances of Research in Antinutritional Factors in Legume Seeds, ed. by Muzquiz M, Hill GD, Cuadrado C, Pedrosa MM, Burbano C. Wageningen Academic Publishers, Wageningen, pp. 159-176 (2004).

49 Rubio LA and Clemente A, In vivo (rat) and in vitro (Caco-2 cells) absorption of amino acids from legume as compared to animal proteins. Arch Anim Nutr 63:413-426 (2009).

50 Mossé J, Nitrogen to protein conversion factor for ten cereals and six legumes or oilseeds. A reappraisal of its definition and determination. Variation according to species and to seed protein content. J Agric Food Chem 38:18-24 (1990). 